\title{
Effect of selective logging on genetic diversity and gene flow in Cariniana legalis sampled from a cacao agroforestry system
}

\author{
J.B. Leal, R.P. Santos and F.A. Gaiotto \\ Departamento de Ciências Biológicas, Centro de Biotecnologia e Genética, \\ Universidade Estadual de Santa Cruz, Ilhéus, BA, Brasil \\ Corresponding author: F.A. Gaiotto \\ E-mail: gaiotto@uesc.br
}

Genet. Mol. Res. 13 (1): 626-635 (2014)

Received January 10, 2013

Accepted July 17, 2013

Published January 28, 2014

DOI http://dx.doi.org/10.4238/2014.January.28.8

\begin{abstract}
The fragments of the Atlantic Forest of southern Bahia have a long history of intense logging and selective cutting. Some tree species, such as jequitibá rosa (Cariniana legalis), have experienced a reduction in their populations with respect to both area and density. To evaluate the possible effects of selective logging on genetic diversity, gene flow, and spatial genetic structure, 51 C. legalis individuals were sampled, representing the total remaining population from the cacao agroforestry system. A total of 120 alleles were observed from the 11 microsatellite loci analyzed. The average observed heterozygosity $(0.486)$ was less than the expected heterozygosity $(0.721)$, indicating a loss of genetic diversity in this population. A high fixation index ( $F_{\text {IS }}$ $=0.325$ ) was found, which is possibly due to a reduction in population size, resulting in increased mating among relatives. The maximum $(1055 \mathrm{~m})$ and minimum $(0.095 \mathrm{~m})$ distances traveled by pollen or seeds were inferred based on paternity tests. We found $36.84 \%$ of unique parents among all sampled seedlings. The progenitors of the remaining seedlings $(63.16 \%)$ were most likely out of the sampled area. Positive and significant spatial genetic structure was identified in this
\end{abstract}


population among classes 10 to $30 \mathrm{~m}$ away with an average coancestry coefficient between pairs of individuals of 0.12 . These results suggest that the agroforestry system of cacao cultivation is contributing to maintaining levels of diversity and gene flow in the studied population, thus minimizing the effects of selective logging.

Key words: Spatial genetic structure; Microsatellites; Atlantic Forest; Jequitibá rosa; Cariniana legalis

\section{INTRODUCTION}

Cariniana legalis Mart. O. Kuntze (Lecythidaceae), popularly known as jequitibá rosa, is one of the largest trees of the Atlantic Forest, reaching $60 \mathrm{~m}$ in height. Its wood has proven commercial value (Carvalho, 1994). This species has been designated in the vulnerable category to extinction (IUCN, 2012), occurring in a limited number in natural habitats (Siqueira et al., 1986) with a population density of 0.8 trees/ha (Harritt and Jesus, 1987).

Reductions in population size can cause loss of alleles and reduced heterozygosity (Young et al., 1996). Populations with reduced size and density contribute to an overall reduction in allele diversity, which becomes intensified when these factors are associated with reduced dispersal of pollen and seeds due to fragmentation effects. The fragmented populations may become genetically and demographically isolated, causing local extinction of species (Nason and Hamrick, 1997).

The best-known commodities grown in agroforestry systems are coffee and cacao, which have multistrata shading systems combining native forest, timber, and fruit. Agroforestry systems contribute to conservation of biodiversity, providing habitat for many species due to landscape connectivity and edge reduction among forests and agricultural areas (Harvey and González Villalobos, 2007). In Bahia, the cacao is grown under the shade of large native trees in an agroforestry system known as 'cabruca'. Studies have shown that the cacao agroforestry system in southern Bahia harbors a considerable number of species, such as small mammals (Pardin, 2004), birds (Faria et al., 2006), ants (Delabie et al., 1999), bats (Faria and Baumgarten, 2007), ferns, and frogs and lizards (Faria et al., 2007). Some authors have argued that traditional agroforestry practices can contribute to in situ conservation of biodiversity through the conservation of tree species on farms, reducing pressure on remaining forests, and thus favoring a natural habitat for several species (Acharya, 2006; McNeely and Schroth, 2006). Agroforestry systems have helped to increase the population density of species through identifying and promoting strategies that aim at sustainable land use that are consistent with the maintenance of local biodiversity (Fifanou et al., 2011).

Gene flow among populations is essential for the microevolution of species, since it allows them to operate as independent evolutionary units (Husband and Barrett, 1996). Gene flow is one of the essential factors in the composition of genetic diversity within a population and between different generations (Dow and Ashley, 1998). A major pathway of gene flow in plant populations has been through pollen dispersal (Hamrick and Nason, 2000). The pollination mechanisms associated with the spatial structure of trees determine how individuals recombine their genes in successive reproductive events, which strongly affects the genetic characteristics of populations (Nason and Hamrick, 1997). 
The selective logging of several species was a common practice in the Atlantic Forest of southern Bahia, which started soon after the discovery of Brazil (Dias, 2010). Studies suggest that logging caused a strong reduction in the number of individuals of existing species (Slik et al., 2002), loss of rare alleles, and reductions in the average number of effective alleles and expected heterozygosity (Silva et al., 2008). In a simulation study, Sebbenn et al. (2008) demonstrated that different tree species respond differently to logging, both with respect to demographic and genetic aspects. Therefore, forest management practices should be speciesspecific, taking into account growth parameters, ecological, and reproductive variables, with a long-term view for the sustainability of forests. Several species of hardwoods have an important gene bank in 'cabruca', since they are practically extinct in remaining Atlantic Forest fragments due to selective logging (Sambuichi, 2002). Currently, the occurrence of C. legalis in Bahia is restricted to small forest fragments and 'cabrucas'. The present study aimed to evaluate genetic parameters in a natural population that was subject to selective logging in the past. Our objectives were to investigate the extent of contemporary gene flow and the spatial genetic structure in a small population of $C$. legalis sampled in a typical 'cabruca' from southern Bahia using microsatellite loci and paternity analysis.

\section{MATERIAL AND METHODS}

\section{Vegetation sampling and DNA extraction}

The census of the Barra of Cedro Farm $\left(14^{\circ} 35^{\prime} 05^{\prime \prime} \mathrm{S}, 39^{\circ} 43^{\prime} 20^{\prime \prime} \mathrm{W}\right)$ population was sampled. We sampled adults and seedlings in an area of $230 \mathrm{ha}$, consisting of cocoa plantations in association with tree species in an agroforestry system known as 'cabruca' located in Pau Brasil in southern Bahia, Brazil. The landscape in this region is a mosaic of remnants of small fragments of the Atlantic Forest, and farms growing cocoa and other crops. To obtain DNA, a total of 51 C. legalis individuals were sampled, including 13 adults and 38 seedlings. Genomic DNA from seedlings and adults were extracted from leaf samples and cambial scrapings according to the protocol described by Doyle and Doyle (1990).

\section{Amplification of microsatellite markers}

The amplification was performed using 11 microsatellite loci, nine of which (Ces03, Ces05, Ces07, Ces10, Ces12, Ces13, Ces14, Ces16, and Ces18) were transferred from Cariniana estrellensis (Guidugli et al., 2009) to C. legalis, and two (Cl05 and Cl11) were developed specifically for $C$. legalis. Tails containing a portion of the plasmid M13 were added to forward primers (CACGACGTTGTAAAACGACC) for detection of amplicons by fluorescence (Oetting et al., 1995). The final volume of each polymerase chain reaction (PCR) was $13 \mu \mathrm{L}$, containing $7.5 \mathrm{ng}$ DNA template, $1 \mathrm{X}\left(\mathrm{NH}_{4}\right)_{2} \mathrm{SO}_{4}$ buffer (Fermentas), $3 \mathrm{mM} \mathrm{MgCl}{ }_{2}$ (Fermentas), $0.25 \mathrm{mg} / \mathrm{mL}$ bovine serum albumin (Sigma), $0.25 \mathrm{mM}$ dNTP (Fermentas), $0.49 \mu \mathrm{M}$ forward and reverse primers, $0.49 \mu \mathrm{M}$ tail M13 primer labeled with HEX, 6-FAM, and NED fluorescence, and $1 \mathrm{U}$ Taq DNA polymerase. Amplifications were performed in the Thermal Cycler GeneAmp 9700 thermocycler (Applied Biosystems). The amplification conditions were $96^{\circ} \mathrm{C}$ for 2 min followed by 35 cycles of $94^{\circ} \mathrm{C}$ for $60 \mathrm{~s}$, temperatures specific for primer annealing (Guidugli et al., 2009) for $60 \mathrm{~s}$, and an extension at $72^{\circ} \mathrm{C}$ for $60 \mathrm{~s}$. After 
35 cycles, a final extension step was run at $72^{\circ} \mathrm{C}$ for $7 \mathrm{~min}$. The PCR products were separated by electrophoresis using an ABI377 genetic analyzer (Applied Biosystems), and filter D genotyping was performed with the aid of GeneScan and Genotyper (Applied Biosystems version 3.1.2). An internal ladder standard labeled with ROX fluorescence was built using a pSPORT vector in lengths of 57, 99, 124, 157, 181, 197, 204, 283, 378, 425, and $651 \mathrm{bp}$ (Brondani and Grattapaglia, 2001).

\section{Diversity and spatial genetic structure in natural populations of $C$. legalis}

Genetic diversity was inferred based on the number of alleles per locus $\left(N_{\mathrm{A}}\right)$, observed heterozygosity $\left(H_{\mathrm{O}}\right)$, expected heterozygosity $\left(H_{\mathrm{E}}\right)$, and allelic richness for each locus using the FSTAT v.2.9.3.2 software (Goudet, 2002). The occurrence of rare alleles in the population (with allele frequency less than 0.05 ) was also detected. Diversity indices were calculated based on allelic identity within individuals (1-Qintra) and within the population (1-Qinter), using the GENEPOP software version 1.2 (Raymond and Rousset, 1995). The levels of inbreeding within samples per locus were verified by the fixation index $\left(F_{\text {IS }}\right)$ using the FSTAT software v.2.9.3.2 (Goudet, 2002). Paternity analysis was performed from the genotypes of the 38 seedlings and 13 adults sampled using the CERVUS 3.0 software (Marshall et al., 1998). As all individuals genotyped were geo-referenced, we also calculated the distances between parents and offspring. The paternity analysis was done without prior knowledge of the alleged parents. For each seedling the most likely candidate father was identified, whose probability of paternity was indicated by the logarithm of odds (LOD) score and the Delta derivative (based on the difference between the LOD score of the most likely parent and the second most likely candidate parent). Only adults and seedlings that genotyped at least 6 of the 11 loci were considered for these analyses. Paternity analysis was estimated in accordance with strict (99\%) and relaxed (95\%) confidence levels.

The spatial genetic structure (SGS) was evaluated using the average coefficient of coancestry $\left(\theta_{\mathrm{xy}}\right)$ estimated between pairs of individuals from the population. The coefficients $\theta_{\mathrm{xy}}$ were calculated using the SPAGEDI program (Hardy and Vekemans, 2002), and the $\theta_{\mathrm{xy}}$ values were calculated based on a set of distance classes to determine the SGS. We use distance intervals of $10 \mathrm{~m}$, with a maximum distance of $100 \mathrm{~m}$. Kinship coefficients were estimated following the method of Loiselle et al. (1995). To test whether the SGS deviated significantly from a random structure, the confidence interval of $95 \%$ was calculated for each observed value and each distance class using 10,000 permutations of individuals in the population.

\section{RESULTS}

The population of $C$. legalis showed a high level of allelic diversity for all analyzed loci. A total of 120 alleles were found from the 11 loci analyzed (Table 1). The Ces10 locus had the highest $N_{\mathrm{A}}$ (26) and Ces07 had the lowest (4) in the sampled population. From the total $N_{\mathrm{A}}$ observed, $60(\sim 50 \%)$ showed low frequency in the population (less than 0.05$)$. The average $H_{\mathrm{O}}$ was less than the $H_{\mathrm{E}}$, indicating that loss of genetic diversity might be occurring in the population. Based on estimates of allelic identity, diversity within individuals was lower than diversity observed among individuals within the population (Table 2). The $F_{\text {IS }}$ was elevated in 9 of the 11 loci, indicating deviations from panmixia. In two loci (Ces05 and C105), the $F_{\text {IS }}$ were negative (Table 2), suggesting a greater number of $H_{\mathrm{O}}$ than $H_{\mathrm{E}}$ in this population. 
Table 1. Estimates of genetic diversity and inbreeding within populations of Cariniana legalis using microsatellite loci.

\begin{tabular}{|c|c|c|c|c|c|}
\hline Locus & Number of alleles & $H_{\mathrm{E}}$ & $H_{\mathrm{O}}$ & Allelic richness & $F_{\text {IS }}$ \\
\hline Ces03 & 11 & 0.825 & 0.737 & 10.77 & 0.106 \\
\hline Ces05 & 5 & 0.541 & 0.868 & 5.00 & -0.606 \\
\hline $\mathrm{Ces} 07$ & 4 & 0.225 & 0.066 & 3.82 & 0.704 \\
\hline Ces 10 & 26 & 0.964 & 0.349 & 25.59 & 0.637 \\
\hline Ces 12 & 18 & 0.918 & 0.275 & 17.79 & 0.7 \\
\hline Ces 13 & 9 & 0.82 & 0.707 & 8.91 & 0.137 \\
\hline Ces 14 & 12 & 0.797 & 0.179 & 11.94 & 0.775 \\
\hline Ces 16 & 11 & 0.842 & 0.552 & 11.00 & 0.344 \\
\hline Ces 18 & 11 & 0.807 & 0.634 & 10.91 & 0.214 \\
\hline $\mathrm{C} 105$ & 8 & 0.625 & 0.78 & 7.78 & -0.248 \\
\hline $\mathrm{Cl11}$ & 5 & 0.568 & 0.205 & 4.97 & 0.639 \\
\hline Mean & 10.91 & 0.721 & 0.486 & 10.77 & 0.325 \\
\hline
\end{tabular}

$H_{\mathrm{E}}=$ expected heterozygosity; $H_{\mathrm{O}}=$ observed heterozygosity; $F_{\mathrm{IS}}=$ fixation índex.

Table 2. Estimates of genetic diversity by individual and within populations based on allelic identity over all loci, where 1-Qintra and 1-Qinter are allelic diversity within individuals and among individuals within the population and $F_{\text {IS }}$ is the fixation index.

\begin{tabular}{lccc}
\hline Sample & 1-Qintra & 1-Qinter & $F_{\text {IS }}$ \\
\hline BC & 0.4775 & 0.7133 & 0.3306 \\
\hline
\end{tabular}

The paternity tests revealed 14 seedlings (36.84\%) whose parents were detected with a strict confidence level of $99 \%$ (Table 3). Our results also showed that 8 of the 13 adult trees $(61.53 \%)$ were contributing offspring to the population. For instance, the adult tree $\mathrm{BC} 22$ was shown to be the probable progenitor of five $(35.71 \%)$ of the seedlings sampled in the population, indicating its reproductive potential and allelic contribution to the next generation. Gene flow via pollen and/or seed dispersal observed in the population ranged from 0.095 to $1055 \mathrm{~m}$ away, with an average of $333.9 \mathrm{~m}$. In order to visualize the distribution of individuals in the area collected, individuals were projected on the plane (Figure 1) of geographic coordinates.

\begin{tabular}{|c|c|c|c|c|c|c|c|}
\hline Offspring ID & $\begin{array}{c}\text { First parent } \\
\text { non-exclusion probability }\end{array}$ & $\begin{array}{c}\text { Second parent } \\
\text { non-exclusion probability }\end{array}$ & $\begin{array}{l}\text { Candidate } \\
\text { father ID }\end{array}$ & $\begin{array}{l}\text { Loci } \\
\text { typed }\end{array}$ & $\begin{array}{l}\text { Pair loci } \\
\text { compared }\end{array}$ & $\begin{array}{l}\text { Pair LOD } \\
\text { score }\end{array}$ & Pair delta \\
\hline $\mathrm{BC} 17$ & $2.68 \mathrm{E}-08$ & $2.68 \mathrm{E}-08$ & $\mathrm{BC} 22$ & 11 & 10 & $1.01 \mathrm{E}+01$ & $1.01 \mathrm{E}+01$ \\
\hline BC19 & 4.42E-08 & $4.42 \mathrm{E}-08$ & $\mathrm{BC} 20$ & 10 & 10 & $5.69 \mathrm{E}+00$ & $5.69 \mathrm{E}+00$ \\
\hline $\mathrm{BC} 21$ & $4.41 \mathrm{E}-07$ & $4.41 \mathrm{E}-07$ & $\mathrm{BC} 22$ & 11 & 11 & $8.38 \mathrm{E}-01$ & $8.38 \mathrm{E}-01$ \\
\hline $\mathrm{BC} 23$ & 4.44E-09 & 4.44E-09 & $\mathrm{BC} 24$ & 10 & 9 & $3.59 \mathrm{E}+00$ & $3.59 \mathrm{E}+00$ \\
\hline BC25 & $1.02 \mathrm{E}-08$ & $1.02 \mathrm{E}-08$ & BC24 & 10 & 10 & $4.27 \mathrm{E}+00$ & $4.27 \mathrm{E}+00$ \\
\hline ВС 30 & $3.11 \mathrm{E}-07$ & $3.11 \mathrm{E}-07$ & ВC32 & 11 & 11 & $1.73 \mathrm{E}+00$ & $1.67 \mathrm{E}+00$ \\
\hline BC 33 & $1.47 \mathrm{E}-06$ & $1.47 \mathrm{E}-06$ & BC40 & 10 & 9 & $4.47 \mathrm{E}+00$ & $3.01 \mathrm{E}+00$ \\
\hline BC34 & $9.70 \mathrm{E}-08$ & $9.70 \mathrm{E}-08$ & BC35 & 10 & 9 & $3.11 \mathrm{E}-01$ & $3.11 \mathrm{E}-01$ \\
\hline $\mathrm{BC} 36$ & 7.38E-09 & 7.38E-09 & BC35 & 10 & 10 & $8.48 \mathrm{E}+00$ & $8.06 \mathrm{E}+00$ \\
\hline $\mathrm{BC} 43$ & $1.04 \mathrm{E}-07$ & $1.04 \mathrm{E}-07$ & $\mathrm{BC} 22$ & 11 & 11 & $6.93 \mathrm{E}+00$ & $9.99 \mathrm{E}-02$ \\
\hline $\mathrm{BC} 45$ & $1.24 \mathrm{E}-08$ & $1.24 \mathrm{E}-08$ & BC44 & 11 & 11 & $1.05 \mathrm{E}+01$ & $2.67 \mathrm{E}+00$ \\
\hline BC47 & $2.02 \mathrm{E}-08$ & $2.02 \mathrm{E}-08$ & BC55 & 9 & 8 & $5.71 \mathrm{E}+00$ & $5.71 \mathrm{E}+00$ \\
\hline BC48 & $9.15 \mathrm{E}-09$ & $9.15 \mathrm{E}-09$ & BC22 & 11 & 11 & $1.82 \mathrm{E}+00$ & $1.82 \mathrm{E}+00$ \\
\hline BC52 & $8.48 \mathrm{E}-07$ & $8.48 \mathrm{E}-07$ & $\mathrm{BC} 22$ & 11 & 9 & $4.25 \mathrm{E}+00$ & $2.16 \mathrm{E}+00$ \\
\hline
\end{tabular}

LOD $=$ logarithm of odds. Delta and LOD scores at strict confidence level of $99 \%$. 


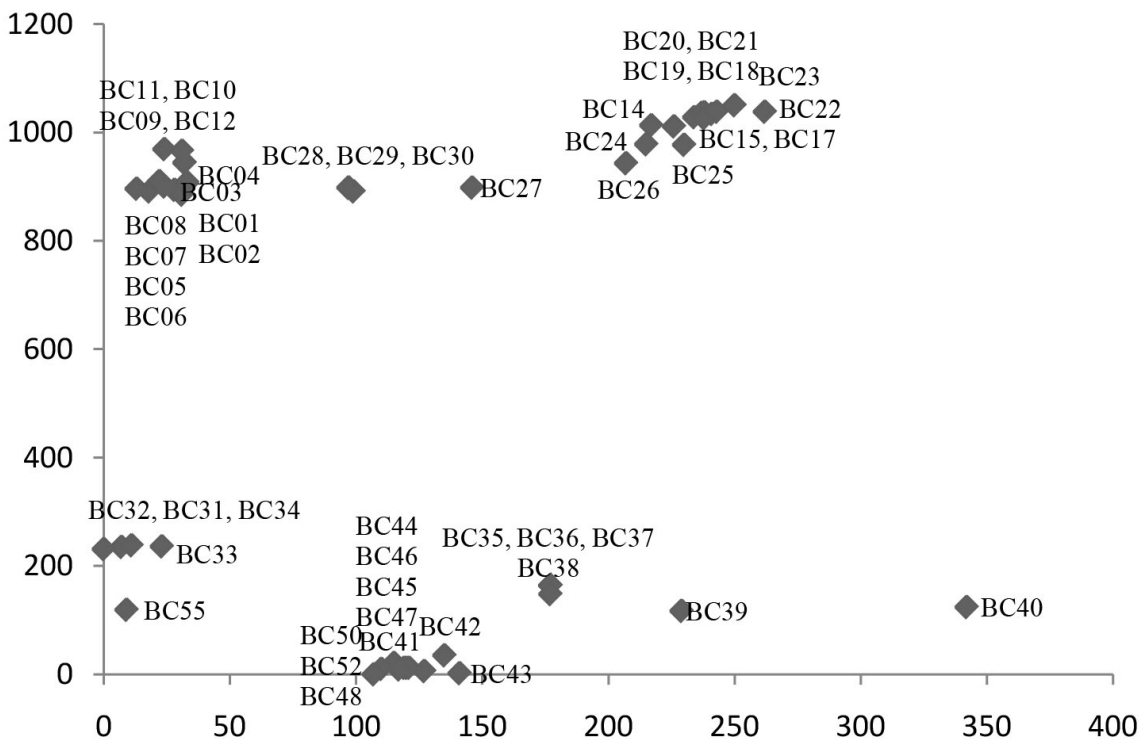

Figure 1. Dispersal in the plane of the individuals sampled in the population.

Significant SGS was found within 10 to $30 \mathrm{~m}$ among trees evaluated (Figure 2), showing an average coefficient of coancestry between pairs of individuals of $\theta_{x y}=0.12$, with a similar relationship found to half-sibs $\left(\theta_{\mathrm{xy}}=0.125\right)$. Among the distance class from 30 to $100 \mathrm{~m}$, no relationship between pairs of individuals was detected within the range of $95 \%$ error estimates, indicating that the coancestry coefficients verified were significantly different from zero.

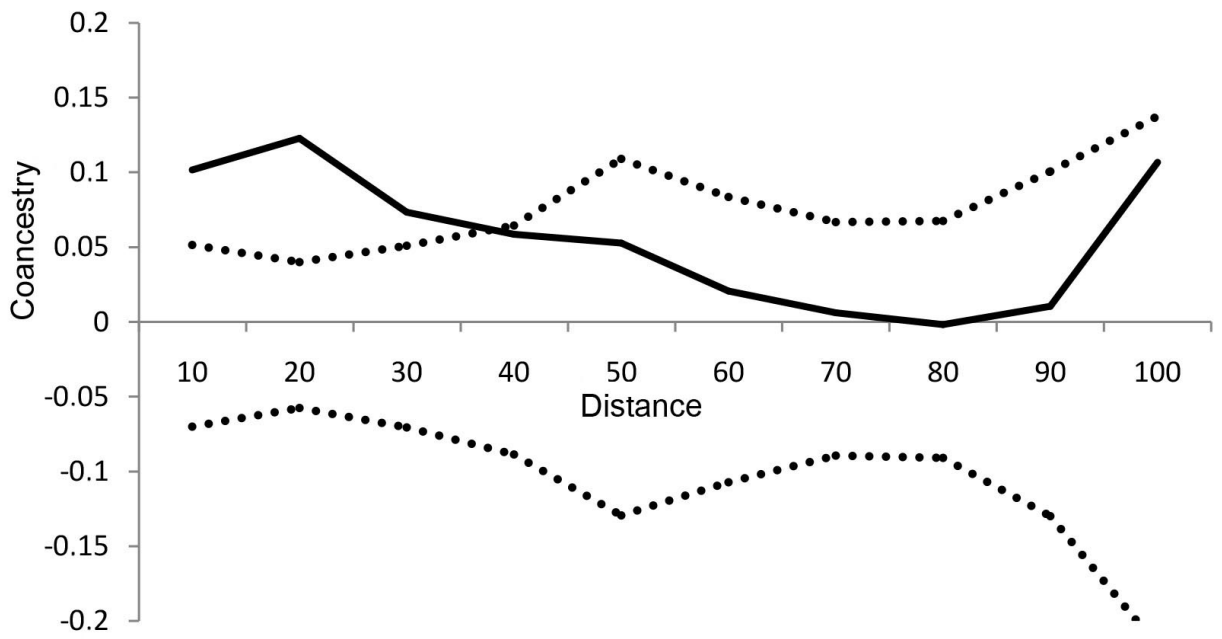

Figure 2. Correlograms of the average kinship coefficients of Cariniana legalis individuals for 10 distance classes with intervals of $10 \mathrm{~m}$. The solid line represents the mean value. The dashed lines represent the $95 \% \mathrm{CI}$ (two rows) of the distribution obtained from the average of 10,000 permutations of the spatial distances between all individuals. 


\section{DISCUSSION}

Agricultural crop expansion and other economic human activities, such as selective cutting of trees with commercial value, have reduced tree populations throughout the world. Currently, $80 \%$ of the Atlantic Forest consists of fragments smaller than 50 ha separated by other small fragments (Ribeiro et al., 2009). Detailed studies are important for understanding the genetic effects resulting from this reduction in population density. These effects can vary among species since they depend on which ecological aspects are affected, such as the number of pollinators and the mating system. This study reflects the current situation facing many tree species along the Atlantic Forest.

Our results showed that there has been a loss in genetic diversity in the population, based on comparison of the average indices of $H_{\mathrm{E}}$ and $H_{\mathrm{O}}$. This result corroborates with the lower observed index of genetic diversity within individuals (1-Qintra) than among individuals within the population (1-Qinter). Considering that the diversity index 1-Qintra reflects the actual diversity within a population, it is likely that this reduction is associated with a reduction in the number of adult tree individuals due to forest fragmentation and intense logging that occurred throughout the region of southern Bahia during the expansion of cacao crops in the 1960s and 1970s. The logging was compounded with a cacao crisis in the 1990s due to witches' broom disease. According to Lowe et al. (2005), a reduction in heterozygosity levels is expected in populations of trees that suffered recent reductions in effective population density. The high incidence of rare alleles $(50 \%)$ observed in the population is worrying since these alleles may disappear or reduce in frequency in the population in subsequent generations. This can happen due to the effects of genetic drift, due to both the history of selective logging and due to the cutting of seedlings' understory, which is common practice in agroforestry systems of cacao. Studies have suggested that although the loss of rare alleles of some trees might result from cutting practices, with proper maintenance of seedlings, rare alleles may still remain in the general population (Silva et al., 2008).

The inbreeding coefficients were negative in 2 of the 11 loci analyzed, indicating an excess of heterozygotes. However, the average $F_{\text {IS }}$ of all loci was positive and high, possibly due to the reduction in the population size, mainly based on the reduced number of adults that would be contributing to offspring in the population, as demonstrated in the paternity analysis. The high inbreeding level detected in this study contrasts with other studies of populations of tree species affected by selective cutting (Cloutier et al., 2007; Silva et al., 2008). Another explanation for the high rate of the fixation average based on all loci could be the presence of null alleles.

Gene flow of pollen and/or seeds observed from the distance between adults (parents) and seedlings (descendants) ranged from 0.095 to $1055 \mathrm{~m}$, with an average of $333.9 \mathrm{~m}$. These analyses showed that seven of the sampled seedlings were located less than $100 \mathrm{~m}$ away from their possible parents, whereas the parents of the other seedlings were more than $100 \mathrm{~m}$ away. The remaining seedlings that were not assigned paternity might represent a low probability of paternity or that they originated from pollen flow and seeds from trees not sampled. The pollen immigration from outside the sampled farm may represent a contribution of pollen and seeds for $63.16 \%$ of seedlings sampled, suggesting long distance gene flow of pollen and/or seeds. The observed long distance pollen dispersal found in this study agrees with the observations in other species of tropical trees of low population density, thereby suggesting that the average distance of pollen dispersal is generally greater than 200 m (Nason and Hamrick, 1997; 
White et al., 2002; Gaiotto et al., 2003; Dick et al., 2003; Carneiro et al., 2007; Cloutier et al., 2007; Eduardo et al., 2008). The agroforestry system to which the population of C. legalis is found most likely favors the action of pollen and seed dispersers. This could explain the high percentage of seedlings $(63.13 \%)$ that probably originated from adult trees located in small forest fragments remaining around the sampled population.

The $\mathrm{BC} 22$ individual was the likely parent to five plantlets, demonstrating the greatest reproductive success in comparison with other adults in the population. Seven heterozygous loci in $\mathrm{BC} 22$ were observed, which shows that it can help to maintain different alleles for the next generation. This individual has a diameter of $2.2 \mathrm{~m}$. Its diameter and height indicate that it is probably one of the founding individuals of this population. The distance between this individual and its descendants ranged from 19 to $1054 \mathrm{~m}$. Reproductive success depends on age and high individual adaptability to local environmental conditions. The adaptability to the environment is associated with several factors, for example, greater pollinator visitation, the distribution of individuals within the population, and pollinator behavior, and thereby pollination rates (Handel, 1983). Several other factors can affect the reproductive success of plants, and further studies are needed to gain a better understanding of these mechanisms.

We verified SGS from individuals up to a $30 \mathrm{~m}$ distance. Individuals between 10 to 30 $\mathrm{m}$ distances showed coefficients of kinship resembling half-sibs. Among the 40- to 100-m distance class, no kinship was detected between individuals. This suggests that the agroforestry system probably favors the dispersal of pollen and seeds over long distances in the sampled region. These results corroborate with the average distance of $333.9 \mathrm{~m}$ between parents and seedlings within the population that was detected in the paternity analysis. Furthermore, selective logging in the past would have minimized the effects of structure due to the withdrawal of some related adults, and a reduction in endogamic crossing in the population. Similar results were found by Silva et al. (2008).

Based on analyses of the different indices of genetic diversity evaluated in this study, as well as contemporary gene flow and kinship analyses, despite the apparent loss of diversity found in this study, levels of diversity in the C. legalis population are maintained that are compatible with populations of other species of trees with good conservation status. This may be due to the small number of generations that have elapsed since selective logging. The agroforestry system of cacao 'cabruca' seems to have contributed to the maintenance of genetic diversity through gene flow within the population and between small forest fragments around the area sampled. However, for the levels of genetic diversity found in this study to be maintained in future generations, proper management is needed that takes into account the average distance of kinship in the population.

\section{ACKNOWLEDGMENTS}

We thank Fundação de Amparo à Pesquisa do Estado da Bahia (FAPESB) and Conselho Nacional de Desenvolvimento Científico e Tecnológico (CNPq) for their financial support of our research and the funding of grants awarded to J.B. Leal (PhD) and F.A. Gaiotto (PQ). We also thank Grupo Chaves Empreendimentos for consenting to the collections and Laboratório de Biotecnologia CEPEC/CEPLAC and LAMOL-UEFS, the agronomist Luis Freire, the field assistant Brasilino Santos, Reinaldo Figueiredo (CEPEC), Ronaldo Carvalho (CEPEC), Karina Gramacho (CEPEC) and Fernanda Ancelmo for technical support. 


\section{REFERENCES}

Acharya KP (2006). Linking trees on farms with biodiversity conservation in subsistence farming systems in Nepal. Biodivers. Conserv. 15: 631-646.

Brondani RP and Grattapaglia D (2001). Cost-effective method to synthesize a fluorescent internal DNA standard for automated fragment sizing. Biotechniques 31: 793-5, 798, 800.

Carneiro FS, Sebbenn AM, Kanashiro M and Degen B (2007). Low interannual variation of mating system and gene flow of Symphonia globulifera in the Brazilian Amazon. Biotropica 39: 628-636.

Carvalho PER (1994). Espécies Florestais Brasileiras: Recomendações Silviculturais, Potencialidades e uso de Madeira. EMBRAPA / CNPF, Brasília.

Cloutier D, Kanashiro M, Ciampi AY and Schoen DJ (2007). Impact of selective logging on inbreeding and gene dispersal in an Amazonian tree population of Carapa guianensis Aubl. Mol. Ecol. 16: 797-809.

Delabie JHC, Nascimento IC and Mariano CSF (1999). Importance de L'agriculture Cacaoyère Pour le Maintien de la Biodiversité: Étude Comparée de la Myrmécofaune de Différents Milieux du Sudest de Bahia, Brésil (Hymenoptera; Formicidae). Proceedings of the XII Internacional Cocoa Research Conference, Salvador.

Dias MH (2010). A floresta mercantil: exploração madeireira na capitania de Ilhéus no século XVIII. Rev. Bras. Hist. 30 : 193-214.

Dick CW, Etchelecu G and Austerlitz F (2003). Pollen dispersal of tropical trees (Dinizia excelsa: Fabaceae) by native insects and African honeybees in pristine and fragmented Amazonian rainforest. Mol. Ecol. 12: 753-764.

Dow BD and Ashley MV (1998). High levels of gene flow in bur oak revealed by paternity analysis using microsatellites. J. Hered. 89: 62-70.

Doyle JJ and Doyle JL (1990). Isolation of plant DNA from fresh tissue. Focus 12: 13-15.

Eduardo A, Lacerda B, Kanashiro M and Sebbenn AM (2008). Long-pollen movement and deviation of random mating in a low-density continuous population of Hymenaea courbaril in the Brazilian Amazon. Biotropica 40: 462-470.

Faria D and Baumgarten J (2007). Shade cacao plantations (Theobroma cacao) and bat conservation in southern Bahia, Brazil. Biodivers. Conserv. 16: 291-312.

Faria D, Laps RR, Baumgarten J and Cetra M (2006). Bat and bird assemblages from forests and shade cacao plantations in two contrasting landscapes in the Atlantic rainforest of southern Bahia, Brazil. Biodivers. Conserv. 15: 587-612.

Faria D, Paciencia MLB, Dixo M, Laps RR, et al. (2007). Ferns, frogs, lizards, birds and bats in forest fragments and shade cacao plantations in two contrasting landscapes in the Atlantic forest, Brazil. Biodivers. Conserv. 16: 2335-2357.

Fifanou VG, Ousmane C, Gauthier B and Brice S (2011). Traditional agroforestry systems and biodiversity conservation in Benin (West Africa). Agrofor. Syst. 82: 1-13.

Gaiotto FA, Grattapaglia D and Vencovsky R (2003). Genetic structure, mating system, and long-distance gene flow in heart of palm (Euterpe edulis Mart.). J. Hered. 94: 399-406.

Goudet J (2002). FSTAT (Version 2.9.3.2.): a computer program to calculate F-statistics. J. Hered. 86: 485-486.

Guidugli MC, Campos T, Sousa ACB, Feres JM, et al. (2009). Development and characterization of 15 microsatellite loci for Cariniana estrellensis and transferability to Cariniana legalis, two endangered tropical tree species. Tech. Note Conser. Genet. 10: 1001-1004.

Hamrick JL and Nason JD (2000). Gene Flow in Forest Trees. In: Forest Conservation Genetics: Principles and Practice (Young A, Boshier D and Boyle T, eds.). CSIRO Publishing, Collingwood, 81-90.

Handel SN (1983). Pollination Ecology, Plant Population Structure, and Gene Flow. Pollination Biology, L. Real, New York.

Hardy OJ and Vekemans X (2002). SPAGEDi: a versatile computer program to analyse spatial genetic structure at the individual or population levels. Mol. Ecol. Notes 2: 618-620.

Harritt MM and Jesus RM De (1987). Ecology of Four Hardwood Species of Atlantic Forest of Brazil. Raleigh: North Carolina State University. Reserva Florestal da CVRD, Linhares.

Harvey CA and González Villalobos JA (2007). Agroforestry systems conserve species-rich but modified assemblages of tropical birds and bats. Biodivers. Conserv. 16: 2257-2292.

Husband BC and Barrett SCH (1996). A metapopulation perspective in plant population biology. J. Ecol. 84: 461-469.

IUCN (2012). International Union for Conservation of Nature Red List of Threatened Species. Version 2012.1. Available at [http://www.iucnredlist.org]. Accessed September 12, 2012.

Loiselle BA, Sork VL, Nason J and Graham C (1995). Spatial genetic structure of a tropical understory shrub, Psychotria officinalis (Rubiaceae). Am. J. Bot. 82: 1420-1425.

Lowe AJ, Boshier D, Ward M, Bacles CF, et al. (2005). Genetic resource impacts of habitat loss and degradation; reconciling empirical evidence and predicted theory for Neotropical trees. Heredity 95: 255-273. 
Marshall TC, Slate J, Kruuk LE and Pemberton JM (1998). Statistical confidence for likelihood-based paternity inference in natural populations. Mol. Ecol. 7: 639-655.

McNeely JA and Schroth G (2006). Agroforestry and biodiversity conservation-traditional practices, present dynamics, and lessons for the future. Biodivers. Conserv. 15: 549-554.

Nason JD and Hamrick JL (1997). Reproductive and genetic consequences of forest fragmentation: two case studies of Neotropical canopy trees. J. Hered. 88: 264-276.

Oetting WS, Lee HK, Flanders DJ, Wiesner GL, et al. (1995). Linkage analysis with multiplexed short tandem repeat polymorphisms using infrared fluorescence and M13 tailed primers. Genomics 30: 450-458.

Pardin R (2004). Effects of forest fragmentation on small mammals in an Atlantic forest landscape. Biodivers. Conserv. 13: 2567-2586.

Raymond M and Rousset F (1995). GENEPOP (version 1.2): population genetics software for exact tests and ecumenicism. J. Hered. 86: 248-249.

Ribeiro MC, Metzger JP, Martensen AC, Ponzoni FJ, et al. (2009). The Brazilian Atlantic Forest: How much is left, and how is the remaining forest distributed? Implications for conservation. Biol. Conserv. 142: 1141-1153.

Sambuichi RHR (2002). Fitossociologia e diversidade de espécies arbóreas em cabruca (mata atlântica raleada sobre plantação de cacau) na região sul da Bahia, Brasil. Acta Bot. Bras. 16: 89-101.

Sebbenn AM, Degen B, Azevedo VCR, Silva MB, et al. (2008). Modelling the long-term impacts of selective logging on genetic diversity and demographic structure of four tropical tree species in the Amazon forest. For. Ecol. Manage. 254: 335-349.

Silva MB, Kanashiro M, Ciampi AY, Thompson I, et al. (2008). Genetic effects of selective logging and pollen gene flow in a low-density population of the dioecious tropical tree Bagassa guianensis in the Brazilian Amazon. For. Ecol. Manage. 255: 1548-1558.

Siqueira ACM de F, Nogueira JCB, Zanatto ACZ, Mariano G, et al. (1986). O jequitibá-rosa - Cariniana legalis (Mart.) O. Ktze., uma espécie em extinção. Bol. Técnico Inst. Florestal 40: 291-301.

Slik JWF, Verburg RW and Kebler PJA (2002). Effects of fire and selective logging on the tree species composition of lowland dipterocarp forest in East Kalimantan, Indonesia. Biodivers. Conserv. 11: 85-98.

White GM, Boshier DH and Powell W (2002). Increased pollen flow counteracts fragmentation in a tropical dry forest: an example from Swietenia humilis Zuccarini. Proc. Natl. Acad. Sci. U. S. A. 99: 2038-2042.

Young A, Boyle T and Brown T (1996). The population genetic consequences of habitat fragmentation for plants. Trends Ecol. Evol. 11: 413-418. 